\title{
Hyperandrogenism? Increased 17, 20-Lyase Activity? A Metanalysis and Systematic Review of Altered Androgens in Boys and Girls with Autism
}

\author{
Benedikt A. Gasser ${ }^{1, *,+}$ (D) Samuel F. Buerki ${ }^{2,+}$, Johann Kurz ${ }^{3,+}$ and Markus G. Mohaupt ${ }^{2}$ \\ 1 Departement für Sport, Bewegung und Gesundheit, University of Basel, 4001 Basel, Switzerland \\ 2 Lindenhofspital Teaching Hospital Internal Medicine, 3001 Bern, Switzerland; \\ samuel.buerki313@gmail.com (S.F.B.); markus.mohaupt@lindenhofgruppe.ch (M.G.M.) \\ 3 Interscience Research Association, 8430 Leibnitz, Austria; john.kurz@a1.net \\ * Correspondence: Benediktandreas.gasser@unibas.ch \\ $\dagger$ First authorship.
}

\section{check for} updates

Citation: Gasser, B.A.; Buerki, S.F.; Kurz, J.; Mohaupt, M.G.

Hyperandrogenism? Increased 17, 20-Lyase Activity? A Metanalysis and Systematic Review of Altered Androgens in Boys and Girls with Autism. Int. J. Mol. Sci. 2021, 22, 12324. https://doi.org/10.3390/ ijms222212324

Academic Editors: Rafael Franco and Edwin Lephart

Received: 26 October 2021

Accepted: 10 November 2021

Published: 15 November 2021

Publisher's Note: MDPI stays neutral with regard to jurisdictional claims in published maps and institutional affiliations.

Copyright: (c) 2021 by the authors. Licensee MDPI, Basel, Switzerland. This article is an open access article distributed under the terms and conditions of the Creative Commons Attribution (CC BY) license (https:/ / creativecommons.org/licenses/by/ $4.0 /)$.

\begin{abstract}
Introduction: There is increasing evidence that steroid hormone levels and, especially, androgen levels are elevated in autism. An overactivity of 17,20-lyase with a higher production of the testosterone precursors dehydroepiandrosterone (DHEA) and androstenedione/androstenediol seems especially present in autism. Methods: An encompassing literature analysis was performed, searching for altered androgens in children with autism and using preferred reporting items for systematic reviews and meta-analysis (PRISMA) guidelines. Included were all studies published before 31 March 2021 found using the following electronic databases: PubMed, Google Scholar, Cochrane Library, Scopus, and TRIP. Eight studies with boys and three studies with girls where steroid hormone measurements were performed from either plasma, urine, or saliva were found and analyzed. Analyses were performed for DHEA(-S/-C), androstenedione/androstenediol, and testosterone. Effect sizes were calculated for each parameter between mean concentrations for children with autism versus healthy controls. Results: Higher levels of androgens in autism were detected, with the majority of calculated effect sizes being larger than one. Conclusions: We found higher levels of the main testosterone precursors DHEA, androstenedione, and androstenediol, likely causing an additionally higher level of testosterone, and an increased 17, 20-lyase activity is therefore implied. Medications already used in PCOS such as metformin might be considered to treat hyperandrogenism in autism following further research.
\end{abstract}

Keywords: extreme male brain theory of autism; androgens; steroid hormones

\section{Introduction}

Endocrine abnormalities are often suggested to be possible etiopathogenetic causes of autism. In the original work of Hans Asperger, the four cases of Fritz, Hellmuth, Harro, and Ernst were analyzed and described with regard to endocrine abnormalities. The involvement of the HPA axis and cholesterol as precursors of steroid hormones as well as sex hormones, androgens in particular, due to their higher prevalence in boys than in girls, were suggested to be altered in children with autism [1,2]. Case reports concerning hypermasculinization in the 1980s and reports about precocious puberty followed [3]. Further associations between elevated androgen levels and fragile $X$ syndrome as well as autism were implied [3] and, as a consequence, autism has been linked with hormonal disbalance for a long time [1,4]. One theory directly addressing steroid hormone change and the higher prevalence in boys than in girls is known as extreme male brain theory [5]. Further analyses have focused on altered steroid hormones while also addressing enzymatic activities and different forms of hormone regulation over the lifespan [6-8]. Moreover, in addition to studies directly analyzing androgens from urine, saliva, serum/plasma, and 
amniotic fluid, clear associations between changes in androgen levels and autism have been observed. Xu et al. (2013) measured higher testosterone levels in mothers of children with autism [9]. Ingudomnukul detected elevated rates of testosterone-related disorders in women with autism [10]. Takasaki et al. correlated salivary testosterone levels with severity of autism, indicating a positive association [11]. Palomba et al. showed that daughters of mothers affected by hyperandrogenic PCOS seem to be at a high risk of autism, possibly due to an unbalanced prenatal exposure to high levels of testosterone [12]. Saenz et al. showed that postnatal testosterone levels were related to autistic behavior in the second year of life [13]. Other studies have elucidated the involvement of the HPA axis and steroid hormones in autism [14]. As the CRH-ACTH system and cortisol are the main mediators of stress, a whole line of evidence acknowledges their variation in children with autism (review by Taylor and Corbett, 2014) [14]. The HPA axis, and its dysregulation in autism in particular, has thus been broadly discussed [9,15-22]. Differences have been found on the level of the hypothalamus $[15,16]$, the pituitary gland $[21,23-25]$, and the adrenal gland $[5,24]$.

A further line of evidence was derived from the cholesterol hypothesis of autism and suggests an increase in cholesterol, the main precursor of steroid hormones [2]. As a result, once again, special attention was given to sex hormones and androgens [5]. Newer studies have directly searched for an explanation for the higher levels of sex hormones, with one line of evidence suggesting retinoic orphan receptor A (RORa) as a key mediator [25-28]. RORa regulates more than 600 genes in the human genome, many of them affecting neuronal plasticity and memory formation; it is differently activated by androgens and estrogens, thereby directly explaining the higher prevalence in boys than in girls [25-28]. Furthermore, the role of RORa regulating aromatase, the enzyme that transforms testosterone to estrogens, has been implied [25-28]. Direct measurements have shown that the aromatase protein is significantly reduced in the frontal cortex of subjects and is strongly correlated with RORa protein levels in the brain [25-28]. However, the detailed mechanism of testosterone predisposing autism remains unclear [6,7]. Genetic research alone has not provided a profound understanding of the underlying causes, and a detailed molecular understanding of the involved pathways is missing [29]. To date, it has been confirmed that testosterone easily passes the blood-brain barrier, and its receptor, the androgen receptor, is expressed in various brain cells and regions [30,31]. In rodents, androgen receptors are expressed in brain areas that are important for the regulation of emotions, cognition, and behavior. Androgens also play a major role in establishing anatomical and functional sexual dimorphism in the nervous system [31-33]. Furthermore, several studies have demonstrated that early exposure to testosterone or to its more active metabolite, dihydrotestosterone, provides neuroprotection $[31,34,35]$ and allows for the modulation of synaptic density and neurite outgrowth in some brain regions [31,36,37].

In conclusion, there are various suggestions of the involvement of altered androgen levels in autism. Further cohort studies imply an overactivity of 17, 20-lyase with higher levels of the testosterone precursors DHEA, androstenedione, and androstenediol found in children with autism (Figure 1). The aim of the current study is a direct product of the above discussion: to systematically analyze and summarize the current evidence of higher androgen levels in children with autism. As a hypothesis with potential falsification, it is stated that DHEA, androstenedione, androstenediol, and testosterone concentrations are not higher in serum/plasma, urine, or saliva in children with autism as compared to those of healthy controls [38]. 
Adrenal steroidogenesis pathway

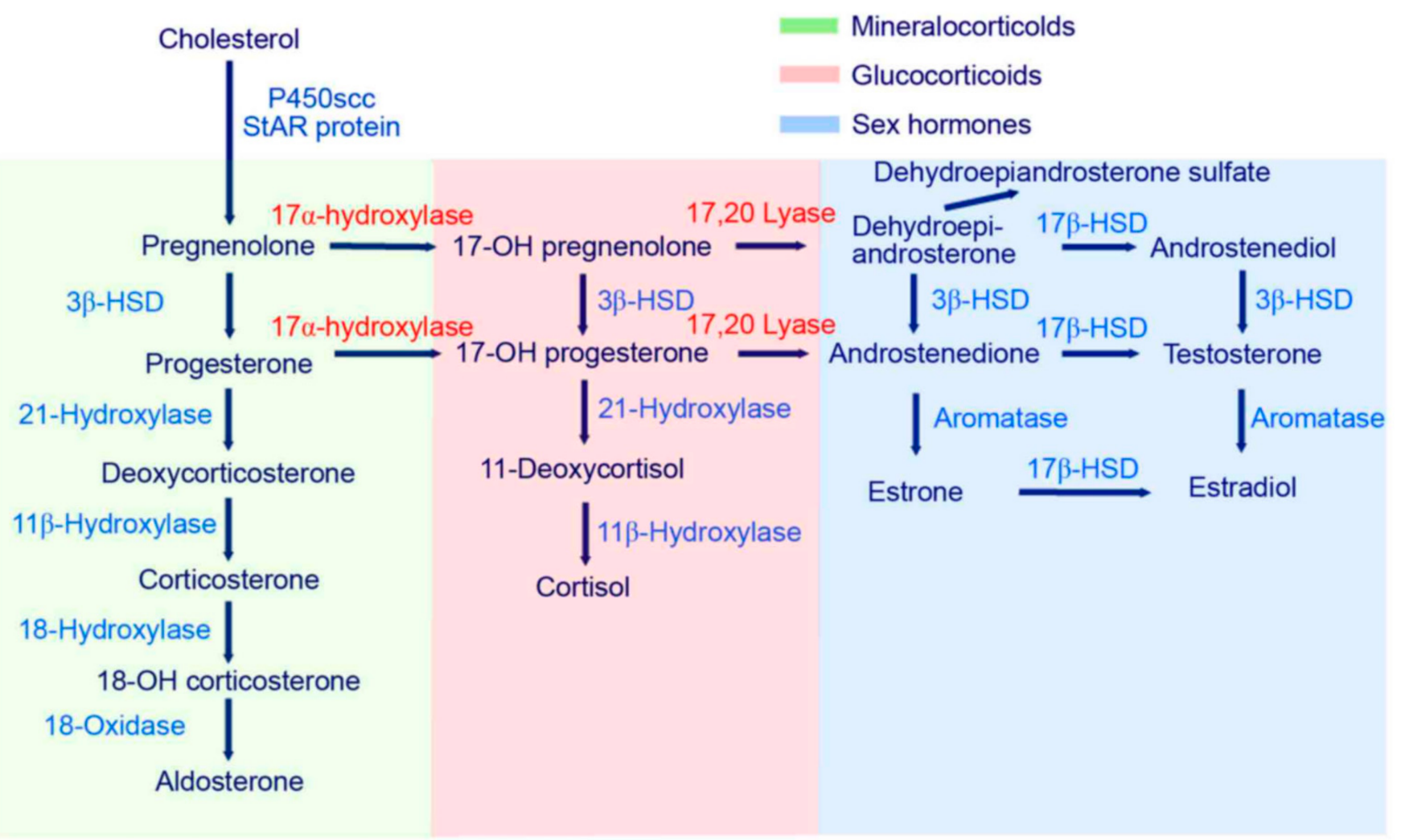

Figure 1. Steroid hormone activity—higher 17, 20-lyase activity should be indicated by higher levels of DHEA, DHEA-S and androstenedione. One step further, higher levels of androstenediol and testosterone in line with increased 17B-HSD and 3B-HSD are indicative of a general hyperandrogenism in autism [39].

\section{Materials and Methods}

\subsection{Search Strategy}

This meta-analysis (Figure 2) was performed using preferred reporting items for systematic reviews and meta-analysis (PRISMA) guidelines. A comprehensive literature search for studies published prior to 31 March 2021 was conducted using the following electronic databases: PubMed, Google Scholar, Cochrane Library, Scopus, and TRIP. The following search terms were employed: "androgens" OR "autism" OR "children" OR "Testosterone" AND/OR "DHEA" AND/OR "Androstenedione" AND/OR "Androstenediole" AND "children" AND "boys" AND "girls" OR "ASD" OR "autism". The literature cited by included studies was also manually searched for additional eligible studies.

\subsection{Study Eligibility Criteria}

Studies involving children with autism diagnosed according to current guidelines (e.g., DSM-IV/V/ICD-10) undergoing analyses of steroid hormones from plasma/serum, urine, or saliva were eligible and included.

\subsection{Data Collection and Analysis}

All eligible studies were screened by two independent reviewers using the selection criteria listed above. Screening first entailed abstract review, followed by full-text review. Any discrepancies were settled through discussion. The following information was extracted from each included study: number of girls and boys with autism and potential healthy controls, levels of steroid hormones (total of all potential steroid hormones mea- 
sured with potentially androgenic activity, androstenedione, androstenediol, DHEA, and testosterone), and probe material (urine, serum/plasma, and saliva).

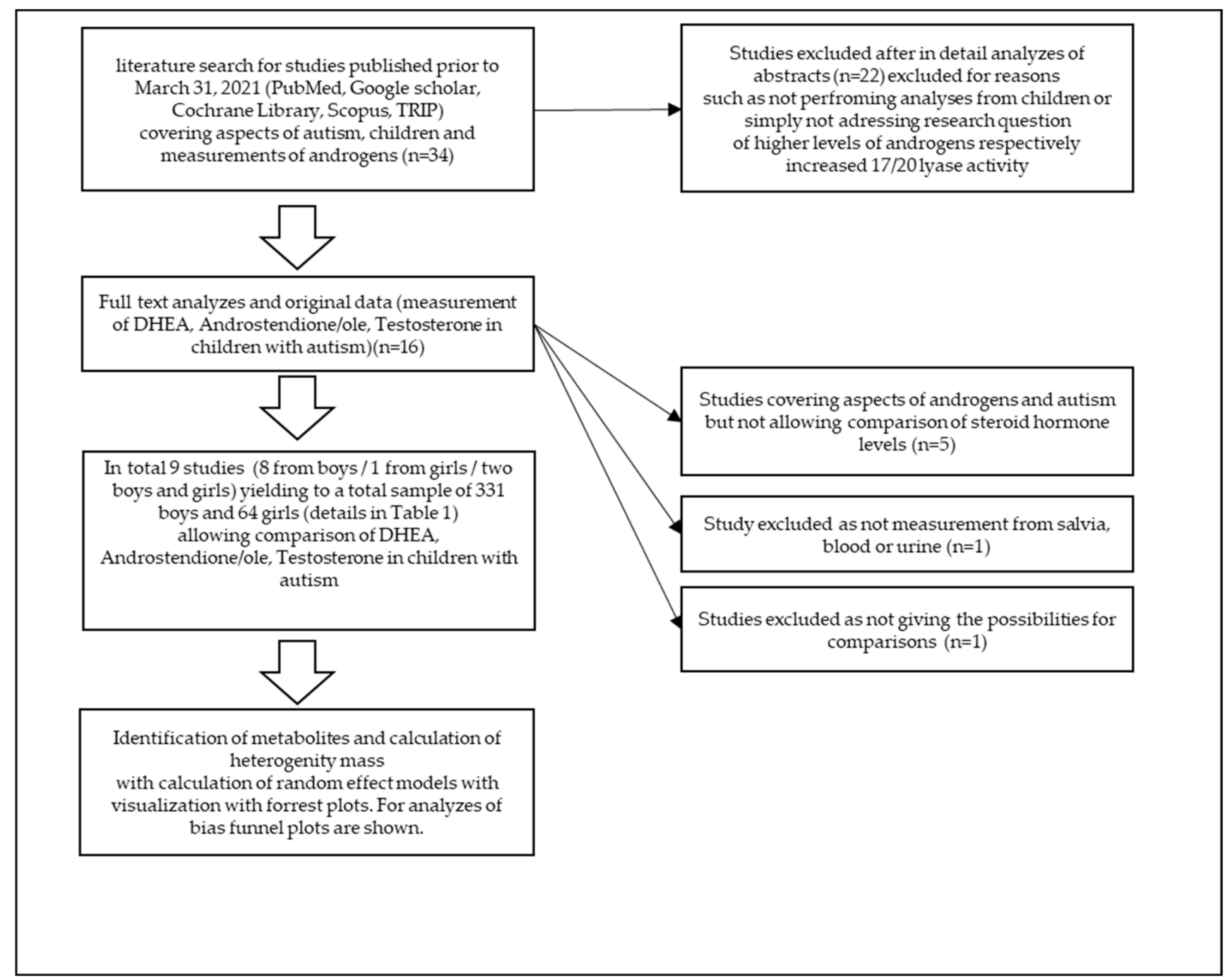

Figure 2. Flow diagram of meta-analysis procedure.

\subsection{Outcomes}

The primary outcome evaluated in this study was increased measured androgen concentrations in children with autism as compared to those in healthy controls in either serum/plasma, urine, or saliva fluid.

\subsection{Publication Bias}

Potential publication bias was assessed using funnel plot analysis [40].

\subsection{Statistical Analysis}

Effect sizes were calculated as the difference in mean change between the ASD group and the comparison group divided by the pooled standard deviation (Hedge's $g$ ) [41]. For the studies of Geier and Geier (2006 and 2007), only reference values and no control group were reported. As such, the difference between the reference values and the measured values in combination with the respective standard deviation was taken in order to calculate effect sizes. Effect sizes were interpreted as small for $\mathrm{d}=0.2$, moderate for $\mathrm{d}=0.5$, and large for $\mathrm{d}=0.8$ or more. Mean differences (MDs) with $95 \%$ confidence intervals (CIs) were calculated for the reported steroid hormone levels for the respective subsample in 
girls and boys with autism versus unaffected controls. Cochrane's $Q$ statistic provides a measure of the variance between the effect sizes (with $p<0.05$ illustrating evidence of heterogeneity), while $\mathrm{I}^{2}$ provides a measure of the amount of variance between studies in terms of heterogeneity [41-43], whereby $\mathrm{I}^{2}>50 \%$ indicates substantial heterogeneity [41]. Here, the heterogeneity variance was estimated using the restricted maximum likelihood method (REML) [42,43]. As study heterogeneity was observed in all the metabolites analyzed except for testosterone in girls with an $\mathrm{I}^{2}$ value larger than 0.5 , random effects models were applied [41-43]. Statistical analyses were conducted using Review Manager software (Version 5.3, Copenhagen: The Nordic Cochrane Center, The Cochrane Collaboration 2014) and $\mathrm{R}$ (version 4.1.1) [43].

\section{Results and Discussion}

Table 1 provides an overview of the studies performing measurements of steroid hormones in blood, urine, or saliva. In total, eight studies on boys were included, with a total sample of 331 boys and 64 girls with autism (Table 1). Twenty years ago, Tordjman et al. (1995) performed an analysis of altered levels of testosterone and the sulfated androgen DEHA-S in plasma, their findings indicating that significantly higher levels of these hormones could not be found in children with autism as compared to healthy controls [3]. This was followed by two studies by Geier and Geier $(2006,2007)$ [44,45]. El-Baz measured serum androgen levels in a group of Egyptian male autistic children and adolescents and their relation to disease severity, where the results showed, in addition to higher androgen levels, an association between disease severity and androgen levels [46]. Croonenberghs et al. analyzed serum testosterone concentrations over time (one daynine measurements) in male autistic children and detected, in contrast to most other studies, lower levels of testosterone in subjects with autism [47]. Majewska et al. distinguished between prepubertal and pubertal children [48] and compared the salivary levels of 22 steroids in prepubertal autistic male and female children from two age groups (3-4 and 7-9 years old) with those in healthy controls. Children with autism had significantly higher salivary concentrations of androgens (androstenediol, DHEA, androsterone, and their polar conjugates) than those of healthy controls. Ruta et al. (2011) measured the three androgens testosterone, androstenedione, DHEA sulfate and found high levels [23]. Gasser et al. measured around 40 metabolites from urine in boys and girls with autism using GC-MS [7,49]. Furthermore, Janšáková et al. (2020) [6] performed measurements from blood using GC-MS analysis of samples of boys with autism, and alterations in steroid hormones and notably higher androgens in boys with autism before puberty compared to healthy controls were observed.

Figure 3 shows the calculated random effects models for boys with autism versus controls for androstenedione/androstenediol, DHEA, and testosterone. Figure 4 shows the calculated random effects models for girls with autism versus healthy controls for androstenedione/androstenediol, DHEA, and testosterone. Furthermore, Figures 5 and 6 show the funnel plots for boys and girls, respectively. 
Table 1. Overview of the analyzed studies.

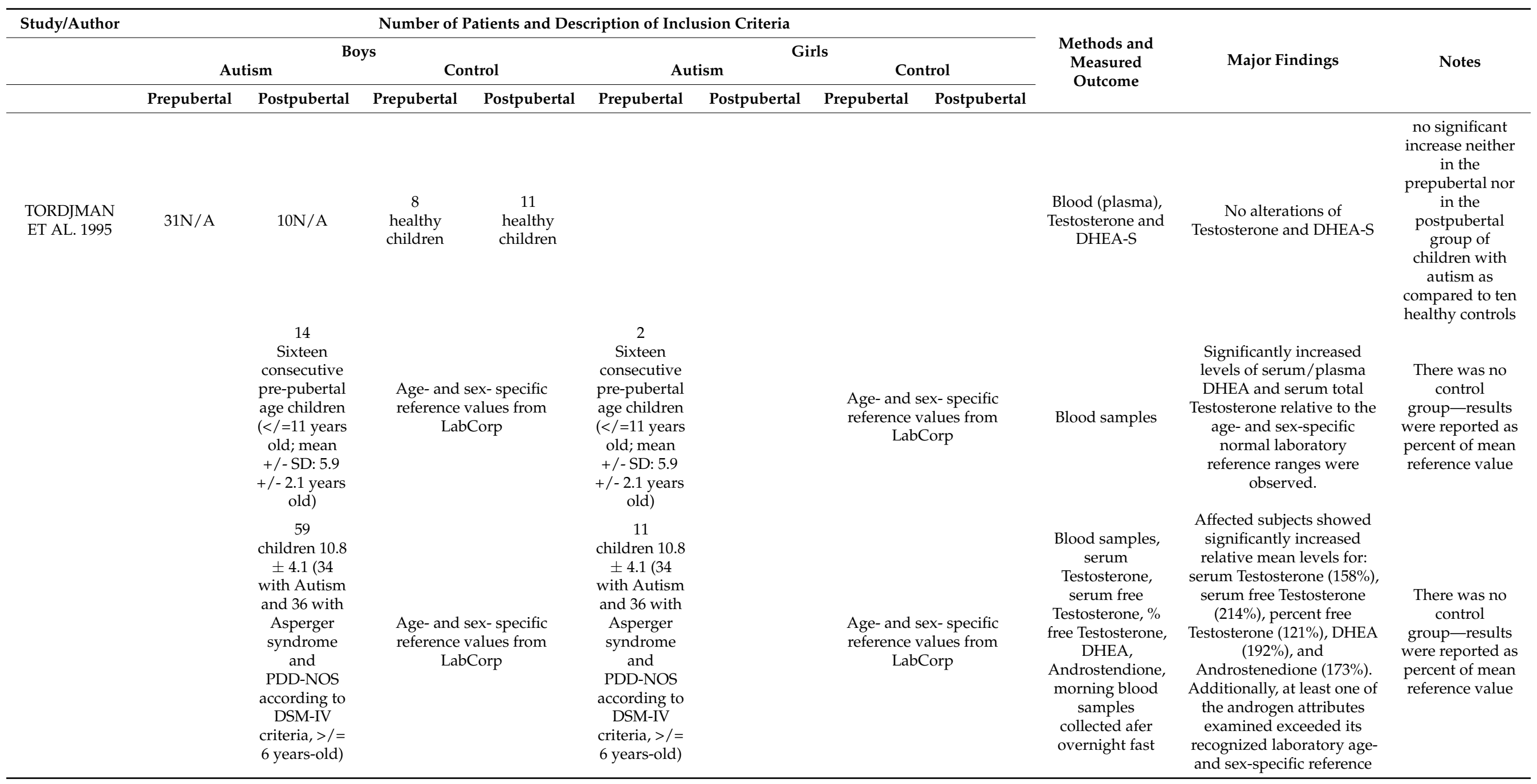


Table 1. Cont.

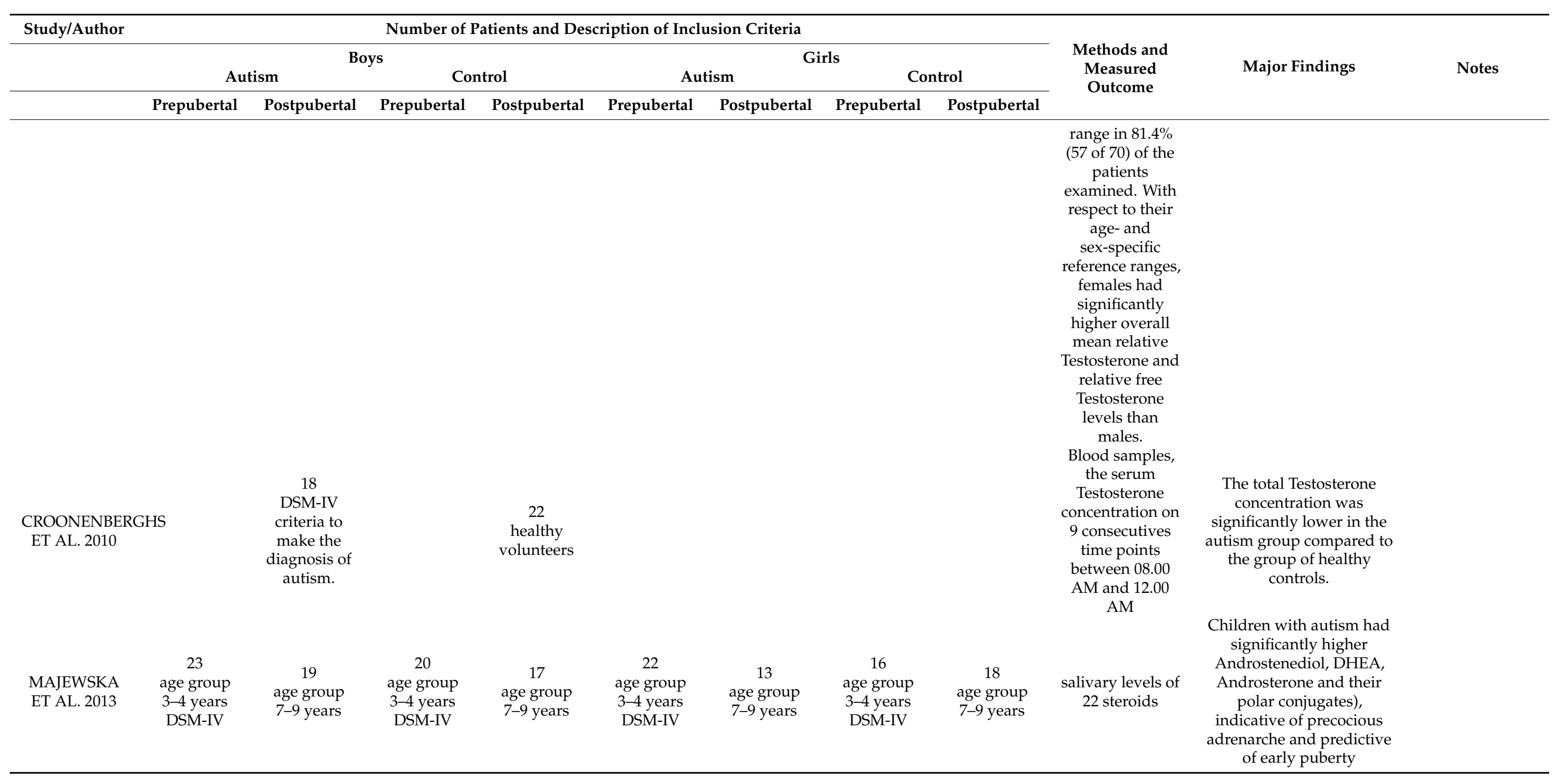


Table 1. Cont.

\begin{tabular}{|c|c|c|c|c|c|c|c|c|c|c|c|}
\hline \multirow[t]{4}{*}{ Study/Author } & \multicolumn{8}{|c|}{ Number of Patients and Description of Inclusion Criteria } & \multirow{4}{*}{$\begin{array}{l}\text { Methods and } \\
\text { Measured } \\
\text { Outcome }\end{array}$} & \multirow{4}{*}{ Major Findings } & \multirow{4}{*}{ Notes } \\
\hline & \multirow{2}{*}{\multicolumn{2}{|c|}{ Autism }} & \multirow{2}{*}{\multicolumn{2}{|c|}{ Control }} & \multirow{2}{*}{\multicolumn{4}{|c|}{ Control }} & & & \\
\hline & & & & & & & & & & & \\
\hline & Prepubertal & Postpubertal & Prepubertal & Postpubertal & Prepubertal & Postpubertal & Prepubertal & Postpubertal & & & \\
\hline $\begin{array}{l}\text { EL-BAZ ET } \\
\text { AL. } 2014\end{array}$ & $\begin{array}{c}30 \\
\text { (DSM-IV), } \\
12(40 \%) \text { had } \\
\text { mild to } \\
\text { moderate } \\
\text { autism and } \\
18(60 \%) \text { had } \\
\text { severe } \\
\text { autism. }\end{array}$ & & $\begin{array}{c}20 \\
\text { sex- and } \\
\text { pubertal- } \\
\text { stage- } \\
\text { matched } \\
\text { children and } \\
\text { adolescents }\end{array}$ & & & . & & . & $\begin{array}{c}\text { Blood (serum), } \\
\text { serum free } \\
\text { Testosterone, } \\
\text { DHEA, } \Delta 4- \\
\text { Androstenedione } \\
\quad(\Delta 4-\mathrm{A}) .\end{array}$ & $\begin{array}{l}11 \text { showed higher free } \\
\text { Testosterone levels, } 9 \text { had } \\
\text { high DHEA, } 12 \text { had high } \\
\Delta 4-\mathrm{A} \text { and } 8 \text { children } \\
\text { showed an elevation of all } \\
\text { androgen levels, an } \\
\text { association was detected } \\
\text { between disease severity } \\
\text { and androgen levels. }\end{array}$ & \\
\hline $\begin{array}{l}\text { GASSER ET } \\
\text { AL. } 2019\end{array}$ & & $\begin{array}{c}41 \\
20 \text { boys with } \\
\text { Asperger } \\
\text { syndrome, } \\
21 \text { boys with } \\
\text { Kanner's } \\
\text { syndrome }\end{array}$ & & $\begin{array}{l}41 \\
\text { matched for } \\
\text { age, weight, } \\
\text { and height }\end{array}$ & & & & & $\begin{array}{l}\text { comprehensive } \\
\text { steroid hormone } \\
\text { metabolite } \\
\text { analysis via gas } \\
\text { chromatography- } \\
\text { mass } \\
\text { spectrometry } \\
\text { from urine } \\
\text { probes } \\
\text { controlled for } \\
\text { creatinine } \\
\text { excretion }\end{array}$ & $\begin{array}{l}\text { Higher levels of most } \\
\text { steroid metabolites were } \\
\text { detected in boys with } \\
\text { Kanner's syndrome and } \\
\text { Asperger syndrome } \\
\text { compared to their matched } \\
\text { controls. These differences } \\
\text { were more pronounced in } \\
\text { affected individuals with } \\
\text { Kanner's syndrome versus } \\
\text { Asperger syndrome. }\end{array}$ & $\begin{array}{c}\text { A specific and } \\
\text { unique pattern } \\
\text { of alteration of } \\
\text { Androsterone, } \\
\text { Etiocholanolone, } \\
\text { Progesterone, } \\
\text { Tetrahydrocorti- } \\
\text { sone, and } \\
\text { Tetrahydrocorti- } \\
\text { sol was } \\
\text { identified in } \\
\text { boys with } \\
\text { Kanner's } \\
\text { syndrome and } \\
\text { Asperger } \\
\text { syndrome. }\end{array}$ \\
\hline $\begin{array}{l}\text { GASSER ET } \\
\text { AL. } 2020\end{array}$ & & & & & & $\begin{array}{c}16 \\
\text { Sixteen } \\
\text { autistic girls } \\
\text { (BMI } 17.4 \pm \\
2.8 ; \text { average } \\
\text { age } 14.3+ \\
4.2 \text { years) }\end{array}$ & & $\begin{array}{c}16 \\
\text { matched } \\
\text { control } \\
\text { cohort for } \\
\text { age, weight } \\
\text { and height } \\
\text { (BMI 16.8 } \pm \\
2.4 ; \text { average } \\
\text { age } 14.4 \pm 4 \\
\text { years) }\end{array}$ & Urine-MS-GC & & \\
\hline
\end{tabular}


Table 1. Cont.

\begin{tabular}{|c|c|c|c|c|c|c|c|c|c|c|c|}
\hline \multirow[t]{4}{*}{ Study/Author } & \multicolumn{8}{|c|}{ Number of Patients and Description of Inclusion Criteria } & \multirow{4}{*}{$\begin{array}{c}\text { Methods and } \\
\text { Measured } \\
\text { Outcome }\end{array}$} & \multirow{4}{*}{ Major Findings } & \multirow{4}{*}{ Notes } \\
\hline & \multirow{2}{*}{\multicolumn{2}{|c|}{ Autism }} & \multirow{2}{*}{\multicolumn{2}{|c|}{ Control }} & \multirow{2}{*}{\multicolumn{4}{|c|}{ Control }} & & & \\
\hline & & & & & & & & & & & \\
\hline & Prepubertal & Postpubertal & Prepubertal & Postpubertal & Prepubertal & Postpubertal & Prepubertal & Postpubertal & & & \\
\hline $\begin{array}{c}\text { JANSAKOVA } \\
\text { ET AL. } 2020\end{array}$ & $\begin{array}{c}86 \\
\text { DSM-V }\end{array}$ & & $\begin{array}{c}24 \\
\text { age and } \\
\text { sex-matched } \\
\text { neurotypical } \\
\text { control } \\
\text { group }\end{array}$ & & & & & & Blood-MS-GC & & \\
\hline $\begin{array}{l}\text { TOTAL PER } \\
\text { CATEGORY }\end{array}$ & 170 & 161 & 94 & 69 & 35 & 29 & 16 & 34 & & & \\
\hline $\begin{array}{l}\text { TOTAL PER } \\
\text { CLASS }\end{array}$ & 331 & & 163 & & 64 & & 50 & & & & \\
\hline
\end{tabular}


Study

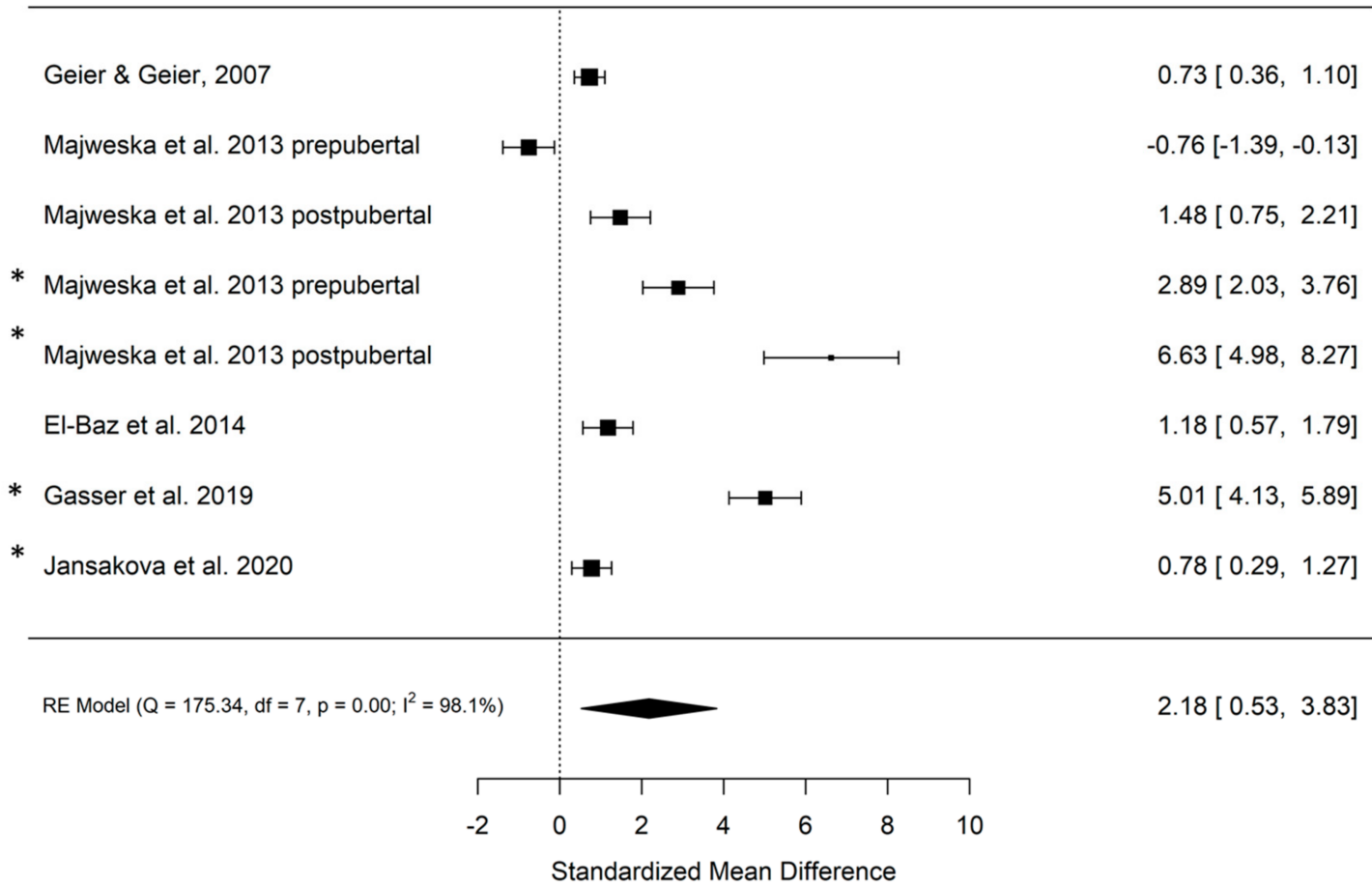

Study

(b) DHEA / DHEA-S* / DHEA-C** in boys

SMD $[95 \% \mathrm{Cl}]$

* Tordjman et al. 1995 prepubertal

* Tordjman et al. 1995 postpubertal Geier \& Geier, 2006

Geier \& Geier, 2007

Majweska et al. 2013 prepubertal Majweska et al. 2013 postpubertal ** Majweska et al. 2013 prepubertal

** Majweska et al. 2013 postpubertal

El-Baz et al. 2014

Gasser et al. 2019

Jansakova et al. 2020

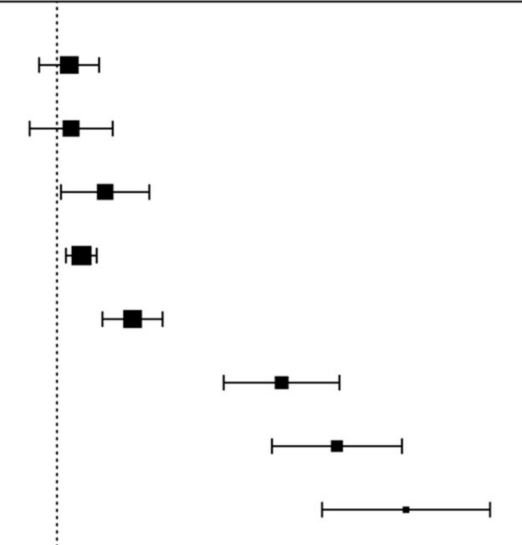

$0.29[-0.43,1.01]$

$0.34[-0.65,1.33]$

1.15 [ $0.09,2.21]$

$0.58[0.21,0.95]$

$1.81[1.09,2.53]$

$5.38[4.00,6.77]$

$6.71[5.15,8.27]$

$8.36[6.35,10.38]$

$1.42[0.79,2.05]$

2.25 [ $1.69,2.80]$

$0.71[0.22,1.19]$

$2.54[0.94,4.14]$

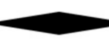

RE Model $\left(Q=171.82, d f=10, p=0.00 ; I^{2}=98.2 \%\right)$

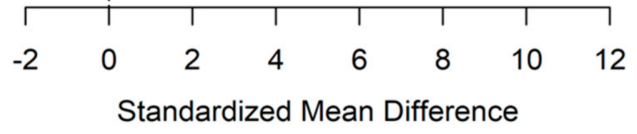

Figure 3. Cont. 
Study

(c) Testosterone / free-Testosterone ${ }^{*}$ in boys

SMD $[95 \% \mathrm{Cl}]$

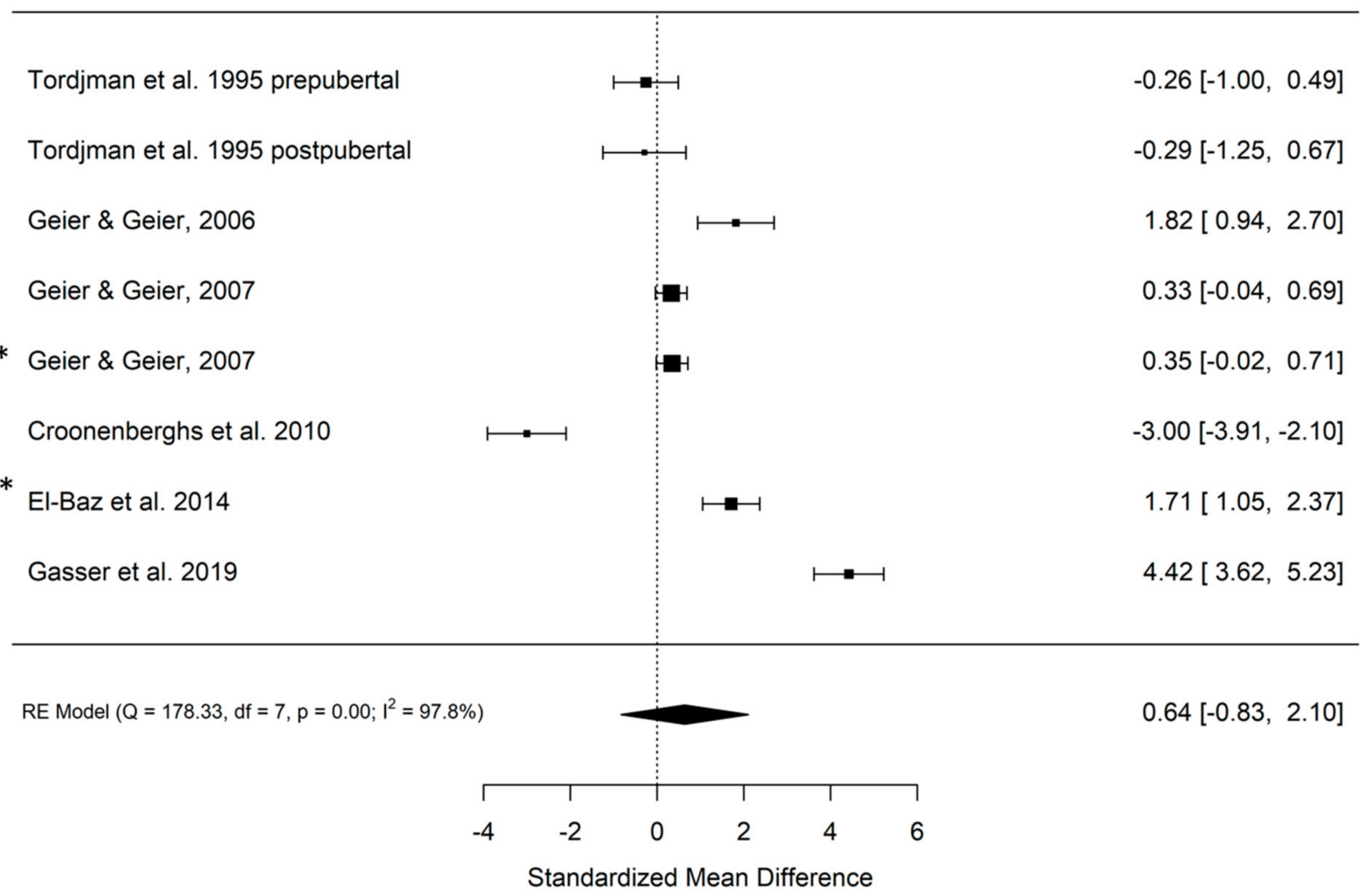

Figure 3. (a-c) Random effects models with significance level, Cochrane $\mathrm{Q}, \mathrm{I}^{2}$, and effect sizes of analyzed metabolites in boys with autism versus healthy controls. (a) Androstenedione/androstenediol indicated with *; (b) DHEA/DHEA-S indicated with *, DHEA-C indicated with **; (c) testosterone/free testosterone indicated with *.

In summary, the aim of this review was to discuss the evidence of altered androgens, with a special focus on 17, 20-lyase activity in girls and boys with autism. The initially stated hypothesis that DHEA, androstenedione, androstenediol, and testosterone levels are not higher in subjects with autism than those in healthy seems rejectable. The general consensus is that androgen levels are higher in children with autism than in healthy controls. As only evidence from children is shown, the development over the lifespan remains indicative. Nevertheless, the study conducted by Ruta et al. (2011) [23], with a relatively large sample of 58 adult subjects (the average age was around 30 years) with autism versus 70 controls, showed significantly increased levels of androstenedione in the adult subjects with autism. However, the levels of DHEA sulfate, free testosterone, and total testosterone in those with autism were not observed to be significantly higher than those in the controls. From the eight analyzed studies focusing on boys in detail, only the oldest one conducted by Tordjman et al. in 1995 and the study by Croonenberghs et al. in 2010 report low androgens in children with autism [47], and the findings by Tordjman et al. in 1995 might be influenced by the relatively heterogeneous nature of the sample [3]. The findings report that mean levels of plasma testosterone and DHEA sulfate were similar in pre- and post-pubertal and children with autism and controls. Croonenberghs et al. (2010) reported testosterone levels over time with nine measurements in affected children versus healthy controls, whereby all measurements showed, in contrast to the general consensus, higher testosterone levels in healthy controls than those in affected children. 
Study

(a) Androstendione/Androstendiol* in girls

SMD $[95 \% \mathrm{Cl}]$

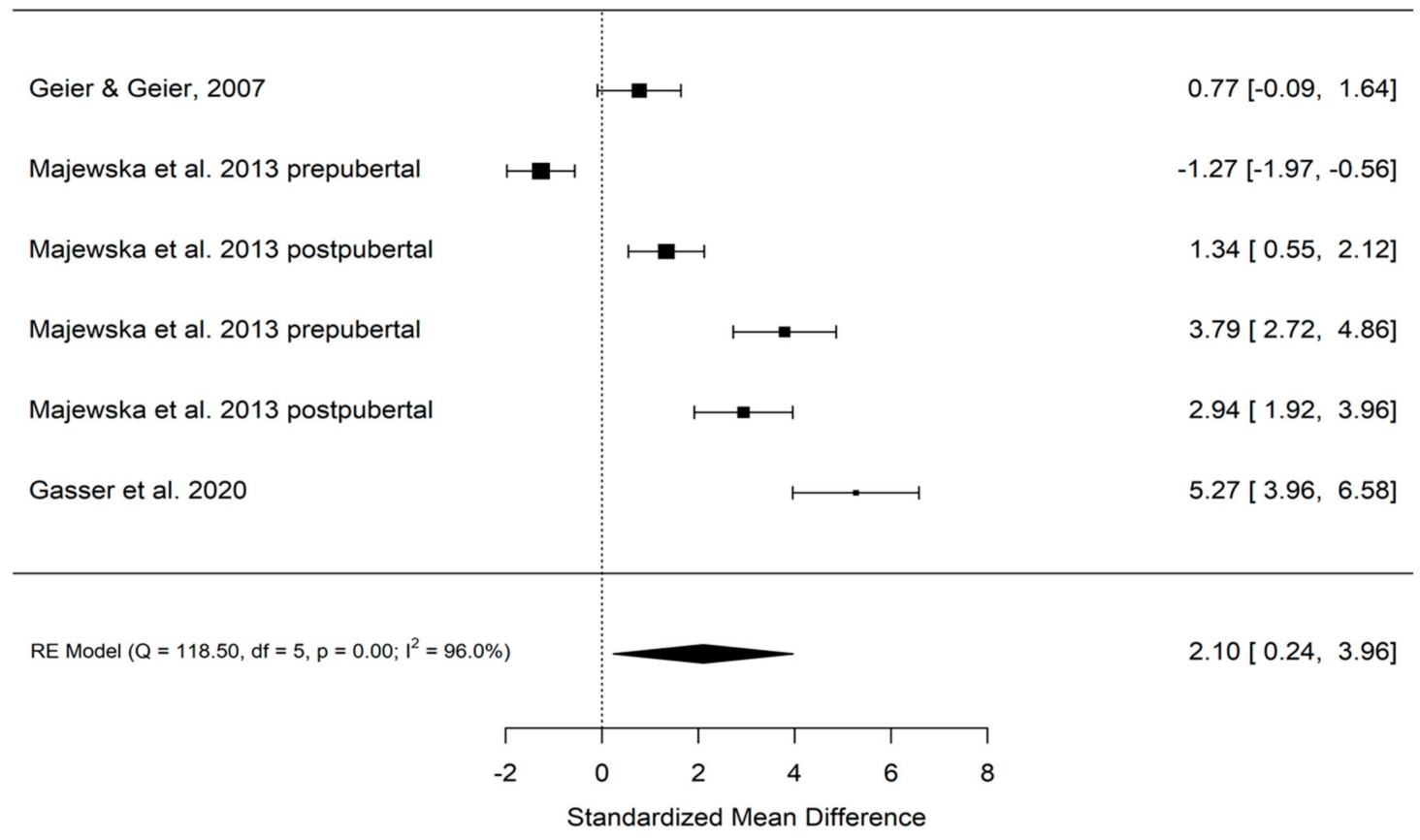

Study

(b) DHEA in girls

SMD $[95 \% \mathrm{Cl}]$

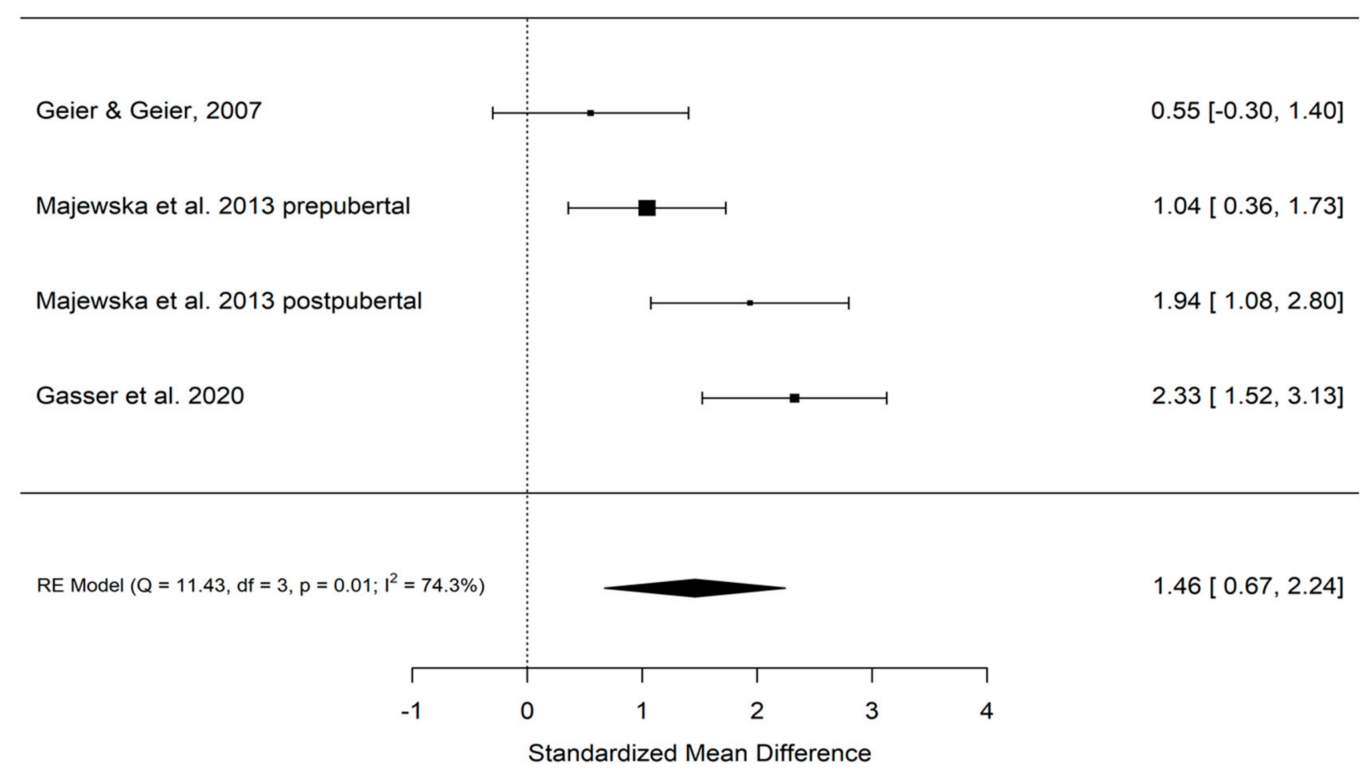

Figure 4. Cont. 
$\begin{array}{ll}\text { Study } & \text { (c) Testosterone/free-Testosterone* in girls }\end{array}$

SMD $[95 \% \mathrm{Cl}]$

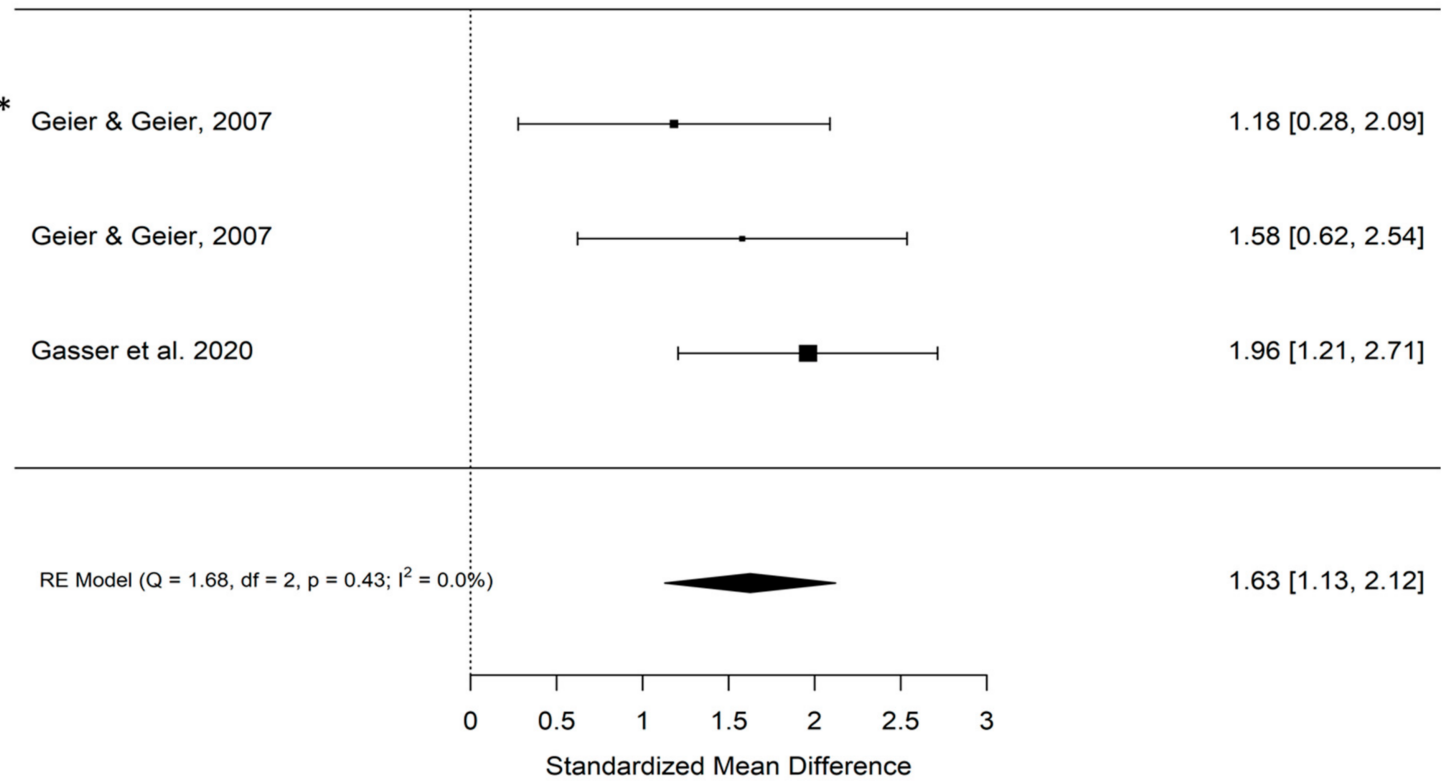

Figure 4. (a-c) Random effects models with significance level, Cochrane $\mathrm{Q}, \mathrm{I}^{2}$, and effect sizes of analyzed metabolites in girls with autism versus healthy controls. (a) Androstenedione/androstenediol indicated with *; (b) DHEA; (c) testosterone/free testosterone indicated with *.

(a) Androstendione/Androstendiole

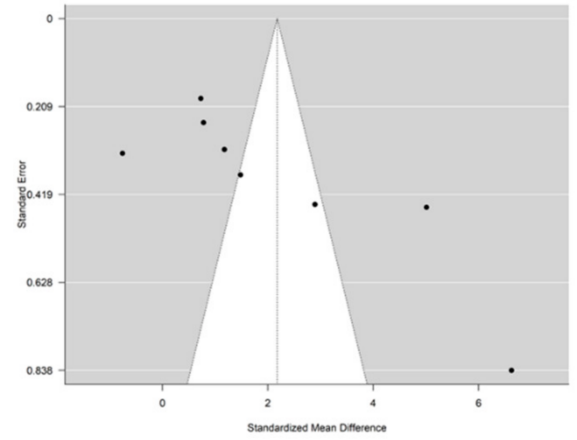

(b) DHEA-(C/S)

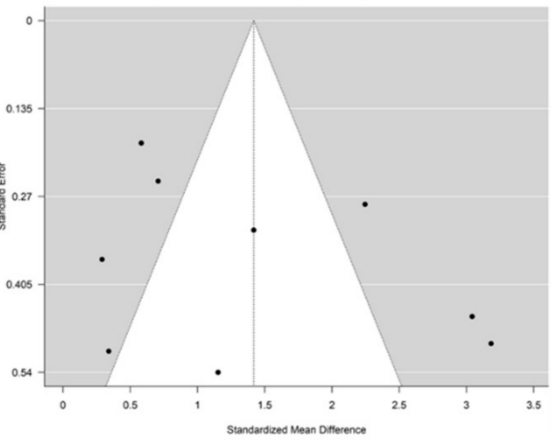

(c) (free)-Testosterone

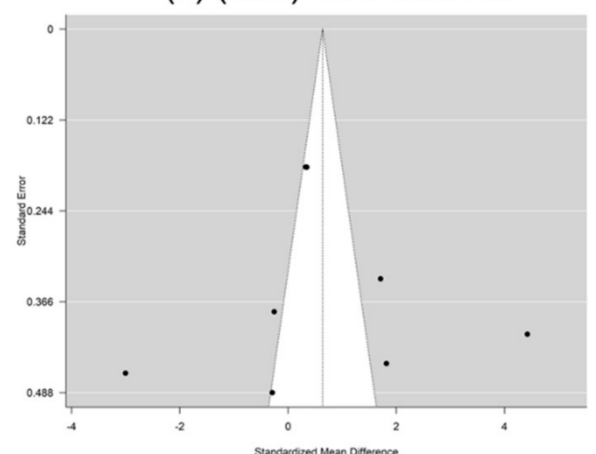

Figure 5. Funnel plots for boys: $x$-axis—standardized mean difference; $y$-axis-standard error for (a) androstenedione/androstenediol, (b) DHEA-(C/S), and (c) (free) testosterone.

(a) Androstendione/Androstendiole

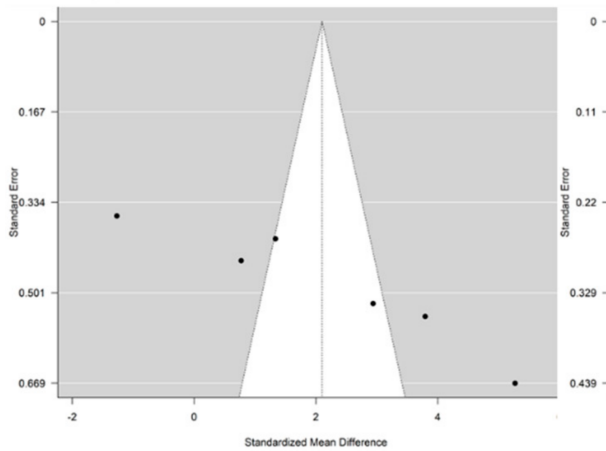

(b) DHEA

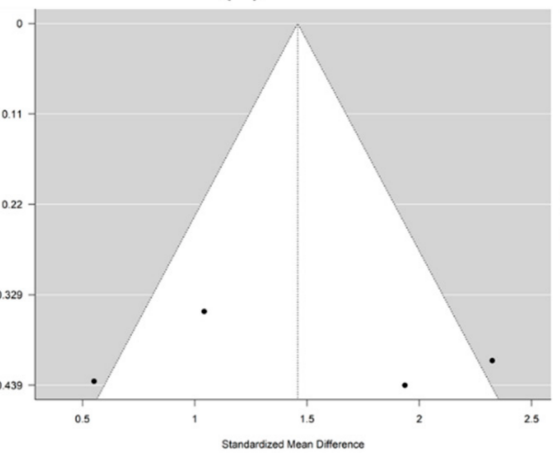

(c) (free)-Testosterone

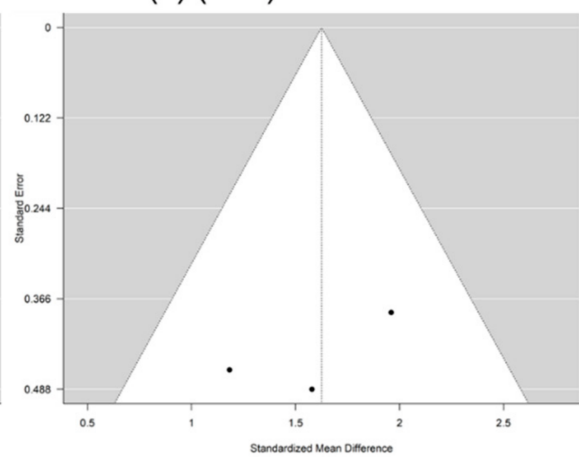

Figure 6. Funnel plots for girls: $x$-axis—standardized mean difference; $y$-axis—standard error for (a) androstenedione/androstenediol, (b) DHEA-(C/S), and (c) (free) testosterone. 
Notably, these analyses attempted to capture evidence concerning the two main products of a potentially increased 17, 20-lyase activity with higher levels of DHEA and androstenedione. The latter is later transformed via 17betaHSD to testosterone (Figure 1). Here, we summarize evidence from eight studies encompassing over 1000 measurements from 321 boys with autism (Table 1). However, it must be kept in mind that there could be a potential publication bias, which might be due to studies, such as those discussing extreme male brain theory, implying that levels of androgens are high in autism [40]. Corresponding funnel plots lessen this concern by showing a relatively symmetric distribution across the board, even though the scattering is strong, especially in girls. However, in girls, evidence is much sparser, with only three studies identified, with a total sample size of 64 girls with autism (Table 1). Except for testosterone levels in boys, the random effect size model (a random effect size model was used in the presence of highly heterogeneous results as seen by a high $\mathrm{I}^{2}$ and Q) shows significant effect sizes for all measured hormones. The effect size itself is relatively constant and high in both genders with an SMD (standardized mean difference) of 2.18 and 2.10 for androstenedione/diol in boys and girls, respectively, and an SMD of 1.42 and 1.46, respectively, for DHEA(-S/C). Therefore, different aspects, such as severity of impairment or development status, must be considered (see Supplementary Table S1). In summary, higher levels of DHEA, androstenedione/androstenediol, and testosterone are implied and, as such, an increased 17, 20-lyase activity seems to prevail. Causes of the detected pattern might be increased oxidative stress, resulting in an increased 17, 20-lyase activity that catalyzes the activity of adrenal P450c17 through p38 $\alpha$ [7,49-52]. Involvement of the tryptophan metabolism, which has an effect via mitochondria on melatonin as a reactive oxygen species inhibitor, might be a further explanation for increased oxidative stress and, as a consequence, increased 17, 20-lyase activity [39]. When further addressing the cause of altered androgens, it was shown in parallel measurements of a unique sample that not only were DHEA and testosterone increased, but, in addition, in plasma measurements, glutathione, plasma cysteine, plasma methionine, serum cystathionine, and serum homocysteine were all significantly decreased [44]. However, there is still much uncertainty regarding the potential mechanism involved. It has to be considered that androgens or testosterone itself do not seem to necessarily induce autism, because in congenital adrenal hyperplasia (CAH) with an excess of androgens, induction of autism does not forcefully occur. Nevertheless, steroids exert organizational and activating actions during brain development $[53,54]$ and modulate neurotransmission either by directly interacting with neurotransmitter receptors or by genomic mechanisms $[27,48,55,56]$. Thus, examination of steroid hormones, and androgens in particular, seems justified [8]. Recent developments using biochemical tools, such as transcriptomics, proteomics, and cellular models, will pave the way to gaining new insights into the underlying pathological pathways [29].

\section{Conclusions}

There are clear indicators that androgens are affected in boys and girls with autism. Here, we present relatively straightforward evidence that DHEA, androstenedione, and testosterone levels are higher in such children and, as a consequence, an increased activity of 17, 20-lyase is present. As this enzyme is upregulated by oxidative stress, therapeutic targeting might result from inhibiting 17, 20-lyase activity via a reduction in oxidative stress. Oxidative stress has previously been noted numerous times to be involved in the pathogenesis of autism and might yield high androgen levels [50,57]. It was shown that unexplained hyperandrogenic oligoanovulation as a main feature of polycystic ovary syndrome (PCOS) and P450c17 phosphorylation selectively increases 17, 20-lyase activity and androgen biosynthesis [50]. Furthermore, mitogen-activated protein kinase 14 (MAPK14, p38 $\alpha$ ) as the kinase responsible for enhancing 17, 20-lyase activity through P450c17 phosphorylation was increased under oxidative stress, yielding increased 17, 20-lyase activity through oxidant-sensitive p38 $\alpha$ signaling pathways. In addition, it significantly induced dehydroepiandrosterone production and increased p38 $\alpha$ phosphorylation and activation [50]. This might explain hyperandrogenism reducing oxidative stress, resulting in a reduction in 
social impairment as a consequence. As previously suggested, metformin, which is already efficiently being used in women with hyperandrogenism due to PCOS, reduces oxidative stress and hyperandrogenism and, as such, this might be one pharmacological target [58].

\section{Ethics and Dissemination Policy}

\subsection{Developmental STAGE}

As development is an important determinant of steroid hormones, age is important in studies examining androgens in ASD cohorts. Even more appropriate are Tanner stages as reference for pubertal status, whereby, for example, the studies conducted by Croonenberghs et al. (2010), El-Baz et al. (2014), and Tordjman (1995) used these to match with controls. Janšáková only analyzed prepubertal boys, while Gasser et al. analyzed postpubertal boys and matches for age and BMI. Geier used specific reference values.

\subsection{Severity of Impairment}

For example, Gasser et al. (2018) clearly distinguished between boys with early infantile autism and Asperger syndrome according to DSM-IV. A different pattern of dysregulation of androgens in Asperger versus early infantile autism was identified. The following study by Janšáková et al. also relied on the DSM-V diagnostic criteria. In summary, severity of impairment plays a role, and associations between increased androgens and severity were made, e.g., by Takagishi et al. 2010. Effect sizes calculated here are presented for prepubertal and postpubertal groups where possible, but they do not control for severity of impairment.

\subsection{Gender}

Autism is more prevalent in boys than in girls. As a consequence, evidence from girls is much sparser than that from boys. Only three studies examining girls could be analyzed; the study conducted by Geier and Geier (2006) with only two girls was not included.

\subsection{Comorbidities and Medication Use}

Comorbidities can play a key role, for example, in fragile $X$ syndrome, where increased androgen levels show a clear association, and fragile $X$ syndrome is associated with autism. As a consequence, there are interaction effects.

\subsection{Diagnostic Differences throughout History and between Samples}

Changing diagnostic criteria for ASD likely impacts the conclusions that can be drawn about steroid hormones in autism. For example, the studies conducted by Gasser et al. distinguished early infantile autism and Asperger syndrome according to DSM -IV (American Psychiatric Association, 1994), while later studies have included children diagnosed with autism spectrum disorders. Thus, earlier studies might have included a narrower range of children and adolescents with autism.

\subsection{Sample Size}

It should also be noted that most sub-samples analyzed have relatively small sample sizes of around twenty (Table 1), and the small sub-samples limit the generalizability of each individual study; as such, very high effect sizes, e.g., detection in the sub-sample of girls with autism by Gasser et al. 2020, should be critically questioned.

\subsection{Methodical Problems}

Here, analyses from blood, urine, and saliva fluid are presented. However, with all forms of measurements, errors can occur. For example, when performing GC-MS from urine, a bias can result when first measuring samples from children with autism and then those from a cohort. During the measurement process, sensitivity loss can result in a systematic measurement error. Thus, measurements from children with autism and 
controls should be analyzed separately. However, studies normally do not report such measurement procedures.

Supplementary Materials: The following are available online at https:/ / www.mdpi.com/article/ 10.3390/ijms222212324/s1, Table S1: Issues and considerations in performed androgen studies in children with autism.

Author Contributions: B.A.G. *: writing—original draft, conceptualization, and methodology; S.F.B. *: writing-review and editing; J.K.: conceptualization; M.G.M.: supervision, resources, funding acquisition, and project administration. All authors have read and agreed to the published version of the manuscript.

Funding: This study was financially supported by the Lindenhofstiftung andthe Gebauer Stiftung.

Institutional Review Board Statement: Not applicable.

Informed Consent Statement: Not applicable.

Data Availability Statement: Data is applicable on request.

Acknowledgments: Special thanks goes to Denis Infanger for his support of our analyses.

Conflicts of Interest: The authors declare no conflict of interest.

\section{References}

1. Asperger, H. Die “Autistischen Psychopathen" im Kindesalter. Arch. Psychiatr. Nervenkrankh. 1944, 117, 76-136. [CrossRef]

2. Gillberg, C.; Fernell, E.; Kočovská, E.; Minnis, H.; Bourgeron, T.; Thompson, L.; Allely, C.S. The role of cholesterol metabolism and various steroid abnormalities in autism spectrum disorders: A hypothesis paper. Autism Res. 2017, 10, 1022-1044. [CrossRef] [PubMed]

3. Tordjman, S.; Anderson, G.M.; McBride, P.A.; Hertzig, M.E.; Snow, M.E.; Hall, L.M.; Ferrari, P.; Cohen, D.J. Plasma androgens in autism. J. Autism Dev. Disord. 1995, 25, 295-304. [CrossRef] [PubMed]

4. Gasser, B.A. The Case of Hellmuth in The Autistic Psychopathy-Suffering from Cushing Syndrome? Glob. J. Intellect. Dev. Disabil. 2018, 4, 555643. [CrossRef]

5. Baron-Cohen, S.; Auyeung, B.; Nørgaard-Pedersen, B.; Hougaard, D.M.; Abdallah, M.W.; Melgaard, L.; Cohen, A.S.; Chakrabarti, B.; Ruta, L.; Lombardo, M.V. Elevated fetal steroidogenic activity in autism. Mol. Psychiatry 2014, 20, 369-376. [CrossRef] [PubMed]

6. Janšáková, K.; Hill, M.; Čelárová, D.; Celušáková, H.; Repiská, G.; Bičíková, M.; Máčová, L.; Ostatníková, D. Alteration of the steroidogenesis in boys with autism spectrum disorders. Transl. Psychiatry 2020, 10, 1-15. [CrossRef]

7. Gasser, B.A.; Kurz, J.; Dick, B.; Mohaupt, M.G. Steroid Metabolites Support Evidence of Autism as a Spectrum. Behav. Sci. 2019, 9, 52. [CrossRef]

8. Gasser, B.A.; Kurz, J.; Dick, B.; Mohaupt, M.G. A reply to high androgens in autism. A reply to 'Alteration of steroidogenesis in boys with autism spectrum disorders'. Nat. Transl. Psychiatry 2021, 11, 278. [CrossRef]

9. Xu, X.-J.; Shou, X.-J.; Li, J.; Jia, M.-X.; Zhang, J.-S.; Guo, Y.; Wei, Q.-Y.; Zhang, X.-T.; Han, S.-P.; Zhang, R.; et al. Mothers of Autistic Children: Lower Plasma Levels of Oxytocin and Arg-Vasopressin and a Higher Level of Testosterone. PLoS ONE 2013, 8, e74849. [CrossRef]

10. Ingudomnukul, E.; Baron-Cohen, S.; Wheelwright, S.J.; Knickmeyer, R. Elevated rates of testosterone-related disorders in women with autism spectrum conditions. Horm. Behav. 2007, 51, 597-604. [CrossRef]

11. Takagishi, H.; Takahashi, T.; Yamagishi, T.; Shinada, M.; Inukai, K.; Tanida, S.; Mifune, N.; Horita, Y.; Hashimoto, H.; Yang, Y.; et al. Salivary testosterone levels and autism-spectrum quotient in adults. Neuroendocrinol. Lett. 2010, 31, 837-841.

12. Palomba, S.; Marotta, R.; Di Cello, A.; Russo, T.; Falbo, A.; Orio, F.; Tolino, A.; Zullo, F.; Esposito, R.; La Sala, G.B. Pervasive developmental disorders in children of hyperandrogenic women with polycystic ovary syndrome: A longitudinal case-control study. Clin. Endocrinol. 2012, 77, 898-904. [CrossRef]

13. Saenz, J.; Alexander, G.M. Postnatal testosterone levels and disorder relevant behavior in the second year of life. Biol. Psychol. 2013, 94, 152-159. [CrossRef]

14. Taylor, J.L.; Corbett, B.A. A review of rhythm and responsiveness of cortisol in individuals with autism spectrum disorders. Psychoneuroendocrinology 2014, 49, 207-228. [CrossRef]

15. Iwata, K.; Matsuzaki, H.; Miyachi, T.; Shimmura, C.; Suda, S.; Tsuchiya, K.J.; Matsumoto, K.; Suzuki, K.; Iwata, Y.; Nakamura, K.; et al. Investigation of the serum levels of anterior pituitary hormones in male children with autism. Mol. Autism 2011, 2, 16. [CrossRef]

16. Bitsika, V.; Sharpley, C.; Sweeney, J.A.; McFarlane, J.R. HPA and SAM axis responses as correlates of self- vs parental ratings of anxiety in boys with an Autistic Disorder. Physiol. Behav. 2014, 127, 1-7. [CrossRef] 
17. Brosnan, M.; Turner-Cobb, J.; Munro-Naan, Z.; Jessop, D. Absence of a normal Cortisol Awakening Response (CAR) in adolescent males with Asperger Syndrome (AS). Psychoneuroendocrinology 2009, 34, 1095-1100. [CrossRef]

18. Marinović-Ćurin, J.; Marinović-Terzić, I.; Bujas-Petković, Z.; Zekan, L.; Škrabić, V.; Đogaš, Z.; Terzić, J. Slower cortisol response during ACTH stimulation test in autistic children. Eur. Child Adolesc. Psychiatry 2007, 17, 39-43. [CrossRef]

19. Hoshino, Y.; Yokoyama, F.; Watanabe, M.; Murata, S.; Kaneko, M.; Kumashiro, H. The diurnal variation and response to dexamethasone suppression test of saliva cortisol level in autistic children. Psychiatry Clin. Neurosci. 1987, 41, 227-235. [CrossRef]

20. Hollocks, M.; Howlin, P.; Papadopoulos, A.S.; Khondoker, M.; Simonoff, E. Differences in HPA-axis and heart rate responsiveness to psychosocial stress in children with autism spectrum disorders with and without co-morbid anxiety. Psychoneuroendocrinology 2014, 46, 32-45. [CrossRef]

21. Hamza, R.T.; Hewedi, D.H.; Ismail, M.A. Basal and Adrenocorticotropic Hormone Stimulated Plasma Cortisol Levels Among Egyptian Autistic Children: Relation to Disease Severity. Ital. J. Pediatr. 2010, 36, 71. [CrossRef]

22. Curin, J.M.; Terzić, J.; Petković, Z.B.; Zekan, L.; Terzić, I.M.; Susnjara, I.M. Lower cortisol and higher ACTH levels in individuals with autism. J. Autism Dev. Disord. 2003, 33, 443-448. [CrossRef]

23. Ruta, L.; Ingudomnukul, E.; Taylor, K.; Chakrabarti, B.; Baron-Cohen, S. Increased serum androstenedione in adults with autism spectrum conditions. Psychoneuroendocrinology 2011, 36, 1154-1163. [CrossRef]

24. Majewska, M.D. Neurosteroids: Endogenous bimodal modulators of the GABAA receptor. Mechanism of action and physiological significance. Prog. Neurobiol. 1992, 38, 379-395. [CrossRef]

25. Hu, V.W.; Nguyen, A.; Kim, K.S.; Steinberg, M.E.; Sarachana, T.; Scully, M.A.; Soldin, S.J.; Luu, T.; Lee, N.H. Gene expression profiling of lymphoblasts from autistic and nonaffected sib pairs: Altered pathways in neuronal development and steroid biosynthesis. PLoS ONE 2009, 4, e5775. [CrossRef]

26. Hu, V.; Sarachana, T.; Sherrard, R.M.; Kocher, K. Investigation of sex differences in the expression of RORA and its transcriptional targets in the brain as a potential contributor to the sex bias in autism. Mol. Autism 2015, 6, 7. [CrossRef]

27. Sarachana, T.; Xu, M.; Wu, R.C.; Hu, V.W. Sex hormones in autism: Androgens and estrogens differentially and reciprocally regulate RORA, a novel candidate gene for autism. PLoS ONE 2011, 6, e17116. [CrossRef]

28. Sarachana, T.; Hu, V. Differential recruitment of coregulators to the RORA promoter adds another layer of complexity to gene (dys) regulation by sex hormones in autism. Mol. Autism 2013, 4, 39. [CrossRef] [PubMed]

29. Broek, J.A.C.; Brombacher, E. Stelzhammer, V.; Guest, P.C.; Rahmoune, H.; Bahn, S. The need for a comprehensive molecular characterization of autism spectrum disorders. Int. J. Neuropsychopharmacol. 2014, 17, 651-673. [CrossRef] [PubMed]

30. Bezdickova, M.; Molikova, R.; Bebarova, L.; Kolar, Z. Distribution ofnuclear receptors for steroid hormones in the human brain: A pre-liminary study. Biomed. Pap. Med Fac. Palacky Univ. Olomouc 2007, 151, 69-71. [CrossRef]

31. Quartier, A.; Chatrousse, L.; Redin, C.; Keime, C.; Haumesser, N.; Maglott-Roth, A.; Brino, L.; Le Gras, S.; Benchoua, A.; Mandel, J.L.; et al. Genes and Pathways Regulated by Androgens in Human Neural Cells, Potential Candidates for the Male Excess in Autism Spectrum Disorder. Biol. Psychiatry 2018, 84, 239-252. [CrossRef] [PubMed]

32. Simerly, R.B.; Chang, C.; Muramatsu, M.; Swanson, L.W. Distributionof androgen and estrogen receptor mRNA-containing cells in the ratbrain: An in situ hybridization study. J. Comp. Neurol. 1990, 294, 76-95. [CrossRef] [PubMed]

33. Xu, X.; Coats, J.K.; Yang, C.F.; Wang, A.; Ahmed, O.M.; Alvarado, M.; Izumi, T.; Shah, N.M. Modular genetic control of sexually dimorphic behaviors. Cell 2012, 148, 596-607. [CrossRef] [PubMed]

34. Hammond, J.; Le, Q.; Goodyer, C.; Gelfand, M.; Trifiro, M.; LeBlanc, A. Testosterone-mediated neuroprotection through the androgen re-ceptor in human primary neurons. J. Neurochem. 2001, 77, 1319-1326. [CrossRef]

35. Pike, C.J.; Nguyen, T.V.; Ramsden, M.; Yao, M.; Murphy, M.P.; Rosario, E.R. Androgen cell signaling pathways involved in neuroprotectiveactions. Horm. Behav. 2008, 53, 693-705. [CrossRef]

36. Hatanaka, Y.; Mukai, H.; Mitsuhashi, K.; Hojo, Y.; Murakami, G.; Komatsuzaki, Y.; Sato, R.; Kawato, S. Androgen rapidly increases dendriticthorns of CA3 neurons in male rat hippocampus. Biochem. Biophys. Res. Commun. 2009, 381, 728-732. [CrossRef]

37. Lustig, R.H. Sex hormone modulation of neural developmentin vitro. Horm. Behav. 1994, 28, 383-395. [CrossRef]

38. Popper, K.R. Logik Der Forschung; Mohr Siebeck: Tübingen, Germany, 1969.

39. Gevi, F.; Zolla, L.; Gabriele, S.; Persico, A.M. Urinary metabolomics of young Italian autistic children supports abnormal tryptophan and purine metabolism. Mol. Autism 2016, 7, 47. [CrossRef]

40. Egger, M.; Smith, G.D.; Schneider, M.; Minder, C. Bias in meta-analysis detected by a simple, graphical test. BMJ 1997, 315, 629-634. [CrossRef]

41. Hedges, L.V. Distribution Theory for Glass's Estimator of Effect Size and Related Estimators. J. Educ. Stat. 1981, 6, 107-128. [CrossRef]

42. Langan, D.; Higgins, J.P.; Simmonds, M. Comparative performance of heterogeneity variance estimators in meta-analysis: A review of simulation studies. Res. Synth. Methods 2017, 8, 181-198. [CrossRef]

43. R Core Team. R: A Language and Environment for Statistical Computing; R Foundation for Statistical Computing: Vienna, Austria, 2021.

44. Geier, D.A.; Geier, M.R. A clinical and laboratory evaluation of methionine cycle-transsulfuration and androgen pathway markers in children with autistic disorders. Horm. Res. 2006, 66, 182-188. [CrossRef]

45. Geier, D.A.; Geier, M.R. A prospective assessment of androgen levels in patients with autistic spectrum disorders: Biochemical underpinnings and suggested therapies. Neuroendocrinol. Lett. 2007, 28, 565-573. 
46. El-Baz, F.; Hamza, R.T.; Ayad, M.S.; Mahmoud, N.H. Hyperandrogenemia in male autistic children and adolescents: Relation to disease severity. Int. J. Adolesc. Med. Health 2014, 26, 79-84. [CrossRef]

47. Croonenberghs, J.; Van Grieken, S.; Wauters, A.; Van West, D.; Brouw, L.; Maes, M.; Deboutte, D. Serum testosterone con centration in male autistic youngsters. Neuroendocrinol. Lett. 2010, 31, 483-488.

48. Majewska, M.D.; Hill, M.; Urbanowicz, E.; Rok-Bujko, P.; Bieńkowski, P.; Namysłowska, I.; Mierzejewski, P. Marked elevation of adrenal steroids, especially androgens, in saliva of prepubertal autistic children. Eur. Child Adolesc. Psychiatry 2013, 23, 485-498. [CrossRef]

49. Gasser, B.A.; Kurz, J.; Dick, B.; Mohaupt, M.G. Are steroid hormones dysregulated in autistic girls. Diseases 2020, 8, 6. [CrossRef]

50. Zhu, W.; Han, B.; Fan, M.; Wang, N.; Wang, H.; Zhu, H.; Cheng, T.; Zhao, S.; Song, H.; Qiao, J. Oxidative stress increases the 17,20-lyase-catalyzing activity of adrenal P450c17 through p38 $\alpha$ in the development of hyperandrogenism. Mol. Cell. Endocrinol. 2019, 484, 25-33. [CrossRef]

51. Miller, W.L.; Tee, M.K. The post-translational regulation of 17,20 lyase activity. Mol. Cell. Endocrinol. 2015, 408, 99-106. [CrossRef]

52. Miller, W.L.; Auchus, R.J. The Molecular Biology, Biochemistry, and Physiology of Human Steroidogenesis and Its Disorders. Endocr. Rev. 2011, 32, 579. [CrossRef]

53. McCarthy, M.M. How it's made: Organisational effects of hormones on the developing brain. J. Neuroendocrinol. 2010, 22, 736-742. [CrossRef] [PubMed]

54. Phoenix, C.H.; Goy, R.W.; Geralerall, A.A.; Young, W.C. Organizing action of prenatally administered testosterone propionate on the tissues mediating mating behavior in the female guinea pig. Endocrinology 1959, 65, 369-382. [CrossRef] [PubMed]

55. Monnet, F.P.; Mahé, V.; Robel, P.; Baulieu, E.E. Neurosteroids, via sigma receptors, modulate the [3H]norepinephrine release evoked by N-methyl-D-aspartate in the rat hippocampus. Proc. Natl. Acad. Sci. USA 1995, 92, 3774-3778. [CrossRef] [PubMed]

56. Zheng, P. Neuroactive steroid regulation of neurotransmitter release in the CNS: Action, mechanism and possible significance. Prog. Neurobiol. 2009, 89, 134-152. [CrossRef]

57. Rossignol, D.A.; Frye, R.E. Evidence linking oxidative stress, mitochondrial dysfunction, and inflammation in the brain of individuals with autism. Front. Physiol. 2014, 5, 150. [CrossRef]

58. Gasser, B.A.; Kurz, J.; Escher, G.; Senn, W.; Mohaupt, M.G. Stress-induced alterations of social behavior is reversible by antagonism of steroid hormones in C57/BL6 mice. Naunyn-Schmiedeberg's Arch. Pharmacol. 2020, 394, 127-135. [CrossRef] 